\title{
Microbiological Production of Surfactant From Agricultural Residuals for IOR Application
}

\author{
G. A. Bala \\ D. F. Bruhn \\ S. L. Fox \\ K. S. Noah \\ D. N. Thompson
}

April 13, 2002 - April 17, 2002

\section{SPE/DOE Thirteenth Symposium on Improved Oil Recovery}

This is a preprint of a paper intended for publication in a journal or proceedings. Since changes may be made before publication, this preprint should not be cited or reproduced without permission of the author.

This document was prepared as a account of work sponsored by an agency of the United States Government. Neither the United States Government nor any agency thereof, or any of their employees, makes any warranty, expressed or implied, or assumes any legal liability or responsibility for any third party's use, or the results of such use, of any information, apparatus, product or process disclosed in this report, or represents that its use by such third party would not infringe privately owned rights. The views expressed in this paper are not necessarily those of the U.S. Government or the sponsoring agency. 


\title{
Microbiological Production of Surfactant From Agricultural Residuals for IOR Application
}

\author{
Gregory A. Bala, Debby F. Bruhn, Sandra L. Fox, Karl S. Noah, and David N. Thompson; Idaho National Engineering and \\ Environmental Laboratory
}

\begin{abstract}
Utilization of surfactants for IOR is an accepted technique with high potential. However, technology application is frequently limited by cost. Biosurfactants (surface-active molecules produced by microorganisms) are commonly used in specialty markets such as food and textiles and have potential for IOR application. Currently, biosurfactants are not widely utilized in the petroleum industry due to high production costs associated with use of expensive substrates and inefficient product recovery methods. The economics of biosurfactant production could be significantly impacted through use of media optimization and application of inexpensive carbon substrates such as agricultural process residuals. Utilization of biosurfactants produced from agricultural residuals may 1) result in an economic advantage for surfactant production and technology application, and 2) convert a substantial agricultural waste stream to a valueadded product for IOR. A biosurfactant with high potential for use is surfactin, a lipopeptide biosurfactant, produced by Bacillus subtilis. Reported here is the production and potential IOR utilization of surfactin produced by Bacillus subtilis (American Type Culture Collection (ATCC) 21332) from starch-based media. Production of surfactants from microbiological growth media based on simple sugars, chemically pure starch medium, simulated liquid and solid potato-process effluent media, a commercially prepared potato starch in mineral salts, and process effluent from a potato processor is discussed. Additionally, the effect of chemical and physical pretreatments on starchy feedstocks is discussed.

This paper presents an overview of previous work. This effort details the progress of research from initial observation of surfactin production from simple growth media through production of surfactin from process effluents from a local potato processor, and finally, potential reactor design for continuous operation. ${ }^{1,2,3,4}$
\end{abstract}

\section{Introduction}

The fermentative (microbiological) production of value added chemicals from biomass derived substrates is the historical essence of industrial biotechnology. Surfactants are a distinct class of IOR chemicals that could be economically produced using biological methods, and applied to the recovery of fossil fuels. Application of biosurfactants for IOR generally falls into the category of Microbial Enhanced Oil Recovery (MEOR).

The application of MEOR can be divided into distinct processes that rely on 1) the beneficial and deliberate introduction of microorganisms into oil bearing formations, or 2) tending to the nutritional requirements of beneficial organisms that are already present in oil bearing formations. In either case, flow conformance or reduction of residual oil saturations can be addressed. The tenet of this work is a third process for MEOR, which is to produce IOR agents in surface facilities using biotechnology and then apply the resulting products without regard to origin.

Biosurfactants, surface-active molecules produced by microorganisms, have numerous desirable properties for application as IOR agents including a fairly broad range of $\mathrm{pH}$ and salt tolerance, low toxicity profiles, and potentially low production cost. Numerous reviews are available on the production and application of biosurfactants. ${ }^{5,67,8,9}$ Bacillus subtilis produces surfactin, a cyclic lipopeptide antibiotic biosurfactant with an aqueous Critical Micelle Concentration (CMC) of $25 \mathrm{mg} / \mathrm{L}$ that lowers the surface tension between water and air to $27 \mathrm{mN} / \mathrm{m}^{7}$

The use of biosurfactants, like numerous other biological products, is limited in low cost/high volume markets due to high costs associated with the media required for growth of the microorganisms and separation of the product (in this case surfactin) from the spent culture.

Previous work at the Idaho National Engineering and Environmental Laboratory (INEEL) demonstrated the feasibility of producing surfactin in cultures of Bacillus subtilis grown on soluble $\operatorname{starch}^{1,10}$ as well as the utility of applying biosurfactants to IOR. ${ }^{10,11,12,13}$ Since that time, we have demonstrated the ability to produce surfactin from agricultural process effluents, ${ }^{2}$ described the impact of effluent pretreatment, ${ }^{3}$ and evaluated the application of novel reactor configurations ${ }^{4}$ for production and separation from actual process effluents.

\section{Materials and Methods}

Microbial Cultures. Bacillus subtilis 21332 was obtained from the American Type Culture Collection and maintained and stored as recommended. ${ }^{14}$ Cells were grown in maintenance broth and harvested in early stationary phase, and $-80^{\circ} \mathrm{C}$ freezer stocks were prepared. Seed inocula were prepared from the freezer stocks by adding one thawed tube of cells $(1 \mathrm{~mL})$ to $50 \mathrm{~mL}$ of Difco nutrient broth and incubating for $18-24 \mathrm{~h}$ at $30^{\circ} \mathrm{C}$ with agitation of $150 \mathrm{rpm}$. The $\mathrm{pH} 6.0$ nutrient broth contained (per liter) $5.0 \mathrm{~g}$ pancreatic digest of gelatin and $3.0 \mathrm{~g}$ beef extract. Typical seed cultures contained $4.0 \pm 0.6 \times 10^{8}$ cells $/ \mathrm{mL}$ at the end of the incubation period.

\section{Analytical Methods.}

Glucose. Glucose was measured using a YSI Model 2700 Glucose Analyzer (Yellow Springs Instrument, Yellow Springs, OH). Samples were centrifuged for $3 \mathrm{~min}$ at $5000 \mathrm{x} \mathrm{g}$ to remove cells and particulates.

Soluble starch. Soluble starch was estimated using the phenol-sulfuric acid assay for total carbohydrates. ${ }^{15}$ Soluble 
starch, assumed to be comprised of linear polymers, was estimated from the total reducing carbohydrate concentration and the glucose concentration by subtracting the glucose $(\mathrm{g} / \mathrm{L})$ from total carbohydrates $(\mathrm{g} / \mathrm{L})$ and multiplying the result by the ratio 162/180 (this accounts for the loss of one water molecule per glucose molecule as free glucose is polymerized to starch).

Insolubles. Frozen samples were thawed, mixed, and centrifuged for $8 \mathrm{~min}$ at $5000 \mathrm{x} \mathrm{g}$. The supernatant was used for surface tension measurement, while the pellet (containing starch particles, cells, and other solids) was refrozen at $-80^{\circ} \mathrm{C}$ and lyophilized to dryness. The estimated weight of cells in each sample was then subtracted from the pellet weight, assuming an average per-cell mass ${ }^{16}$ of $10^{-12} \mathrm{~g} / \mathrm{cell}$. The estimate for insolubles (starch plus other solids) was calculated by difference.

Surface tension. Surface tensions were measured by video image analysis of inverted pendant drops as previously described. ${ }^{17}$ All measurements were made on cell- and solidfree supernatants obtained by centrifugation.

Surfactin isolation and Critical Micelle Concentration. Surfactin was isolated by precipitation as previously described, ${ }^{18}$ except that the crude powder was not washed with methylene chloride (except for one sample as mentioned in text) or filtered. The $\mathrm{pH}$ of the cell-free supernatant was adjusted to 2.0 by addition of concentrated $\mathrm{HCl}$, precipitating the surfactin. The precipitate was collected by centrifugation, resuspended in nanopure water, and its $\mathrm{pH}$ adjusted to 7.0. The suspension was then frozen at $-80^{\circ} \mathrm{C}$ and quantitatively lyophilized to dryness. The crude lyophilized powder was then used to estimate the $\mathrm{CMC}$, in nanopure water, as previously described. ${ }^{19}$

Fourier Transform Infrared (FTIR) Spectroscopy. FTIR was performed using a Nicolet Magna 750 FTIR spectrophotometer equipped with a MCT-B (HgCdTe midband) detector. Transmission FTIR spectra of pellets were averaged from 50 scans measured from 4000 to $400 \mathrm{~cm}^{-1}$ with $4 \mathrm{~cm}^{-1}$ resolution. A $\mathrm{KBr}$ background spectrum was subtracted from each spectrum. Measurements were performed on $\mathrm{KBr}$ wafers containing $2.5 \mathrm{wt} \%$ of pure surfactin or $3.8 \mathrm{wt} \%$ of crude precipitate in $\mathrm{KBr}$, respectively.

Surfactin Concentrations. Surfactin concentrations to support bioreactor development were measured by highperformance liquid chromatography as described by Lin and Jiang, ${ }^{20}$ using a Supelco LC-18 column $(250 \times 4.6 \mathrm{~mm}, 5-\mu \mathrm{m}$ particle size). Separation was achieved by elution on a gradient of $10 \mathrm{mM} \mathrm{KH}_{2} \mathrm{PO}_{4}(\mathrm{pH}$ 6) and $100 \%$ methanol at 0.5 $\mathrm{mL} / \mathrm{min}$ as follows: (a) 0-30 $\mathrm{min}, 70-73.4 \mathrm{vol} \%$ methanol; and (b) 30-80 $\mathrm{min}, 73.4-95.4 \mathrm{vol} \%$ methanol. Samples were centrifuged for $10 \mathrm{~min}$ at $3500 \mathrm{x}$ g and filtered through a 0.22 $\mu \mathrm{m}$ syringe filter prior to analysis. The injection volume was $500 \mu \mathrm{L}$. Surfactin was measured by absorbance at $210 \mathrm{~nm}$. Purified surfactin (cat. no. S-3523, Sigma) was used as a standard. All surfactins eluted from 34-80 min; thus, total surfactin was quantified in samples as the sum of the areas of the peaks eluting in that time period.
Potato Process Effluent Pretreatment Methods. Highsolids and low-solids potato process effluents were tested as substrates for surfactin production. Tests used 1/10-diluted effluents, unamended and amended with trace minerals or corn steep liquor. Potato process effluent streams were obtained from a potato processor in southeast Idaho. Dilution of the streams was performed to obtain workable slurries of each. Control experiments were conducted using a purified potato starch (Sigma), rendered soluble by boiling in distilled water for $30 \mathrm{~min}$. Initial substrate data for the diluted potato process waste streams and for the potato starch control are presented in Table 1.

Pretreatments included autoclaving, filtration, and dilute acid hydrolysis. Autoclaving was done at $121^{\circ} \mathrm{C}$ for $20 \mathrm{~min}$. To prepare the filtered effluent, diluted low-solids potato process effluent was centrifuged for $10 \mathrm{~min}$ at $1180 \mathrm{x} \mathrm{g}$. The slurry in the lower half of the tube was discarded, and the supernatant slurry was filtered through P8 filter paper (Fisher, average pore size $20 \mu \mathrm{m}$ ). The filtrate was used as the final substrate after autoclaving. Acid hydrolysis of diluted lowsolids effluent was done by autoclaving after adding 1.42 , 2.85 , or $5.69 \mathrm{~mL}$ of concentrated $\mathrm{H}_{2} \mathrm{SO}_{4}$ to the undiluted effluent and adding sufficient nanopure water to give $500 \mathrm{~mL}$ of 1:10 diluted low solids effluent containing $0.5,1.0$, or 2.0 $\mathrm{wt} \% \mathrm{H}_{2} \mathrm{SO}_{4}$. The acid hydrolyzed substrates were neutralized with $10 \mathrm{~N} \mathrm{NaOH}$ before use.

Airlift Reactor. The airlift reactor (Figure 1) used here was $91.4 \mathrm{~cm}$ long $\times 9.52 \mathrm{~cm}$ i.d. with a $33.02 \mathrm{~cm}$ long $\times 2.54$ $\mathrm{cm}$ i.d. draft tube, both fabricated from Lexan. ${ }^{\mathrm{TM}}$ The top and bottom plates were fabricated from 316 stainless steel. Aeration was provided from the bottom at $1.5 \mathrm{~L} / \mathrm{min}$ through a $3.18 \mathrm{~mm}$ o.d. stainless steel tube with $160.051-\mathrm{mm}$ holes. Effluent collection and level control were achieved using an overflow tube. Dissolved oxygen (DO) and $\mathrm{pH}$ were monitored using sterilized probes $(0.61-\mathrm{m}$ Ingold DO probe and 0.61-m Mettler Toledo $\mathrm{pH}$ probe, respectively), inserted through the head plate, which fixed the headspace height at $0.48 \mathrm{~m}$ and the liquid volume at $3 \mathrm{~L}$. A thermocouple was inserted below the liquid level within a thermowell and used with a temperature controller and heating tape to maintain the reactor at $30^{\circ} \mathrm{C}$. Three liters of medium (either potato process effluent or potato starch) was inoculated in the reactor with 50 $\mathrm{mL}$ of $B$. subtilis grown on Trypticase Soy Broth. Foam collection from the top of the column was achieved using an inverted funnel. During continuous operation, fresh autoclaved medium was pumped from a refrigerated $\left(4^{\circ} \mathrm{C}\right) 50$-L carboy into the column at various dilution rates.

\section{Production of Surfactin from Starch Substrates}

Various sources of carbohydrate may be used for biological production of value added chemicals. However, utilization of corn and molasses are dominant in the United States. ${ }^{21,22}$ In addition to corn and molasses, potato processing residuals represents a significant source of carbohydrates. If theoretical yield were realized, use of potato processing wastes to 
biologically produce glycerol could completely saturate the current and projected markets. ${ }^{23}$ Previous studies at the INEEL demonstrated the utility of starch as a viable feedstock for surfactant production. ${ }^{10}$

A preliminary screening of five commercially available starches (corn, potato, rice, soluble and wheat) was performed in a mineral salts medium described by Sheppard and Cooper, ${ }^{24}$ modified such that the glucose carbon source was substituted. Purified starch components used in media preparation were purchased from Sigma Chemical. Results were considered positive if surface tensions below $30 \mathrm{mN} / \mathrm{m}$ were achieved with spent media.

Additionally, four potato based media were evaluated. Medium 1 was a modified potato medium from ATCC, media 2 and 3 simulated liquid and solid potato waste effluents from a processing plant, and medium 4 was a modified mineral salts medium using purified potato starch. Exact compositions of media used have been previously reported. ${ }^{1}$ Potatoes (Russet Burbank) were used to prepare media types $1-3$. Unpeeled potatoes $(60 \mathrm{~g} / \mathrm{l})$ were rinsed, trimmed and boiled. To simulate potato waste, only the exterior flesh and peel were retained for media preparation. Simulated liquid effluents were filtered (cheescloth) while simulated solid effluents were not.

Growth studies were performed in triplicate with biotic and abiotic controls. Cells were enumerated using the PetroffHauser method. ${ }^{25}$ Supernatants (cells removed at $4811 \mathrm{x}$ g for 20 minutes at $10^{\circ} \mathrm{C}$ ) were analyzed for carbohydrates (soluble glucose and total soluble carbohydrate), surface tension, and surfactant recovery. The surface tension for all purified starches tested were below $30 \mathrm{mN} / \mathrm{m}$. Additionally, there was no statistical difference in the mean surface tension between the starch sources when included in a mineral salts media. Although there was no significant difference between starch types, there was a significant difference with respect to concentration. Utilization of different potato concentrations to simulate a process effluent resulted in no statistical reduction of surface tension when used up to $5 \mathrm{~g} / \mathrm{L}$. However, when used in concentrations greater than $25 \mathrm{~g} / \mathrm{L}$, surface tensions of about $28 \mathrm{mN} / \mathrm{m}$ resulted. It was concluded from these studies that potato alone supplied enough nutrients to produce meaningful biosurfactant. Total soluble carbohydrate analysis indicated that in general a higher initial soluble carbohydrate concentration yielded a lower surface tension.

The total carbohydrate and glucose consumption of the four media indicated that potato was a viable substrate for surfactant production by $B$. subtilis. The simulated solid potato process effluent produced the highest cell concentration and required fewer added nutrients to generate surfactant than the established potato medium. The addition of yeast extract and peptone to the broth, as in the established potato medium, was not necessary to decrease surface tensions. Potato substrates alone were utilized by the organisms and resulted in decreased surface tensions. Even though the liquid potato medium initially had a limited supply of carbohydrate available, surface tensions were still reduced.

When the surfactin produced by growth on simulated potato effluent (solid) was isolated by methylene chloride extraction, the CMC indicated the crude surfactin was about $25 \%$ pure when compared with the lowest CMC reported in the literature. ${ }^{18}$ This study indicated that $B$. subtilis can produce surfactant from potato substrates and that traditional carbon sources for surfactant production can be replaced with potato substrates.

\section{Production of Surfactin from Agricultural Process Effluents}

To confirm the presence of surfactin in the cultures, FTIR spectra of commercially obtained purified surfactin and the crude precipitate from a low-solids culture were obtained. Results of FTIR analysis are presented in Figure 2.

B. subtilis 21332 grew on all three potato substrates, regardless of additions of exogenous nutrients. Growth rates were higher in all effluent-based media versus the purified starch media control. With respect to cell growth, low-solids medium was slightly better than high-solids medium. The addition of nutrients (corn steep liquor (CSL), trace minerals) resulted in slightly higher growth rates. However, higher growth rates (mediated by nutrient addition) did not result in lower surface tensions. Furthermore, the addition of CSL, had a detrimental effect on surfactin production (as measured by surface tension), while addition of trace minerals had no effect.

It is possible that the higher growth rates associated with low-solids media were a result of increased initial concentrations of free glucose and the subsequent growth of contaminating indigenous bacteria. Low-solids media had an initial free glucose concentration of $0.44 \mathrm{~g} / \mathrm{L}$ in comparison to $0.009 \mathrm{~g} / \mathrm{L}$ in the control. Additionally, high-solids media also outgrew the purified starch control but had only a little more free glucose in the medium $(0.016 \mathrm{~g} / \mathrm{L}$ vs. $0.009 \mathrm{~g} / \mathrm{L})$. Addition of CSL did not affect growth rates to the extent expected.

When specific growth rates were measured for cells growing in the low-solids, high-solids, and purified starch and compared to autoclaved, biotic, and abiotic controls for each media, the impact of contaminating biota was revealed. The contaminants were comprised of vegetative cells as well as spores. For autoclaved, inoculated low-solids effluent, a growth rate of $0.447 \mu\left(\mathrm{h}^{-1}\right)$ was observed. For unautoclaved, inoculated low-solids media the growth rate was $0.418 \mu\left(\mathrm{h}^{-1}\right)$.

Literature reports the production of surfactin by $B$. subtilis in mid to late log phase..$^{10,18,19}$ Although this work is consistent with those observations, the bulk of surfactin production by $B$. subtilis while growing on process effluents was produced in late log phase or very early stationary phase. This was manifested by the observation that the final concentrations of surfactin at $72 \mathrm{~h}$ (well into stationary phase) were always well in excess of the CMC. Minimum surface tensions (indicating that the CMC has been reached) were obtained very near the onset of stationary phase. All cultures (except the biotic purified starch control) were in log phase within $4 \mathrm{~h}$ of inoculation until about 12 hours of culture, at which time they transitioned into stationary phase. In all cases, most of the 
soluble starch degradation occurred during stationary phase, while insoluble starch was degraded during log phase. Glucose levels increased early in the stationary phase and declined after the soluble starch was depleted. This suggests that the free glucose content of the medium limited both early cell growth and later surfactin production.

Data for low-solids effluent are presented as Figure 3, high-solids effluent not shown.

It is clear from the substrate utilization data that $B$. subtilis does express $\alpha$-amylase (the enzyme responsible for starch hydrolysis) in the process effluents. For effluent based media and the purified starch control, B. subtilis efficiently solubilized the insoluble starch, and hydrolyzed soluble starch to free glucose. CSL-amended media deviated from this, perhaps because of the high initial concentration of free reducing sugars added by the CSL. The CSL-amended media for both high-solids and low-solids exhibited higher initial growth rates than other media, but lacked the late glucose accumulation characteristic of amylolytic activity, suggesting that amylase production was inhibited by the added carbohydrates in the CSL. Additionally, the experiments indicated that if the medium was first autoclaved, B. subtilis somewhat competed for resources and produced surfactin in the presence of germinating spores that survived. However, the spores that survived germinated and grew substantially (as supported by the growth rate data above). Without autoclaving the medium to kill vegetative indigenous cells, the $B$. subtilis inoculum did not compete well with the indigenous microbes. It is probable that the indigenous cells growing alongside $B$. subtilis consumed extra carbon and decreased the yields.

Low-solids effluent was clearly a better substrate for surfactin production than high-solids effluent, however not as good as optimized purified starch media. This was shown by evaluating the grams of carbon consumed per gram of surfactin produced. Optimized media resulted in three times more surfactin per gram than the low-solids effluent and over nine times more than high-solids effluent.

Although it is suggested by the data, it is not clear whether surfactin yields from low-solids effluent would increase to the level seen with purified starch medium if the indigenous cells and their spores were completely killed before inoculation with $B$. subtilis. It is improbable that cells growing at less than $25 \%$ of the rate seen in the low-solids could consume enough carbon to lower the surfactin yield by $66 \%$. Addition of minerals to the low-solids effluent only slightly increased the yields, indicating a near-constant drain on the carbohydrate pool. This may indicate the added minerals were consumed by the indigenous bacteria rather than by $B$. subtilis, or that there was simply no effect on the growth of either. This will be an important consideration since the value of the lost surfactin production could potentially outstrip the cost of complete sterilization of the medium, depending on the end use.

It was concluded that low-solids potato process effluents offer promise as carbon and nutrient sources for surfactin production by B. subtilis. Addition of CSL not only inhibited starch hydrolysis, but also greatly lowered surfactin production. Addition of minerals to the medium had little effect on surfactin production from low-solids or high-solids potato process effluent. The high-solids effluent stream did not work as well for surfactin production, and is not recommended as a surfactin production substrate. Heattreatment to kill vegetative indigenous cells was necessary to achieve surfactin production from both low-solids and highsolids effluents. However, use of the effluents without complete sterilization, thereby allowing contaminating bacteria to remain, reduced the surfactin yield from the starch by $66 \%$ or more. Depending on the economics and the end use of the surfactin, this may make complete sterilization unnecessary.

\section{The Effect of Pretreatment of Agricultural Process Effluents on Surfactin Production}

Although low-solids potato processing effluent was demonstrated to be a viable substrate for surfactin production, the possibility of improving its use through pretreatment was an unanswered question. The positive effect of autoclaving the effluent to reduce the contaminant biota was known, as was the negative effect of adding exogenous nutrients (in the form of CSL). This study evaluated the effect of several pretreatments on surfactin production from low-solids potato process effluent. The selected pretreatments were autoclaving, removal of particulates, and dilute acid hydrolysis. Pretreatment of high-solids effluent was not performed as it was ruled out as an effective substrate in the previous study. ${ }^{2}$

The average composition of low-solids effluent as received is delineated in Table 2 and the effect of pretreatments on initial substrate composition are summarized in Table 3. Some variation in initial glucose and starch levels of the undiluted low-solids effluent were present as received from the processor. Initial glucose in the biotic low-solids medium control was $1.41 \mathrm{~g} / \mathrm{L}$, with soluble starch and insolubles at 14 and $5.5 \mathrm{~g} / \mathrm{L}$, respectively. Autoclaving the effluent lowered the initial glucose by about $20 \%$, increased the soluble starch by $18 \%$, and nearly doubled the insolubles content. As expected, filtering the diluted low-solids before autoclaving had little effect on glucose content. However, the soluble starch content increased by $45 \%$, and the total insolubles content was essentially unchanged. Acid hydrolysis increased the glucose content from hydrolysis of the starch, thereby decreasing the soluble starch content. Again, the insolubles content increased relative to the unautoclaved effluent.

In all cases except the biotic purified starch and abiotic low-solids controls, log phase growth was over by $12 \mathrm{~h}$. For the biotic purified starch control, $24 \mathrm{~h}$ were required. Removal of particulates by filtration had little effect on growth. The specific growth rate averaged over $12 \mathrm{~h}$ for the filtered lowsolids culture was slightly higher than that for the low solids culture. Addition of acid to the low-solids effluent and autoclaving increased the specific growth rate when $0.5 \mathrm{wt} \%$ $\mathrm{H}_{2} \mathrm{SO}_{4}$ was added. To $95 \%$ confidence, there was a very slight overlap of growth rates associated with low-solids effluent receiving $0.5 \%$ and $1.0 \%$ acid. However, doubling the acid 
concentration to $2.0 \%$ decreased the specific growth rate relative to $0.5 \mathrm{wt} \%$, although this was about equal to the $0 \%$ acid medium (low-solids). Addition of acid to $2.0 \mathrm{wt} \%$ also had a detrimental effect on cell growth, decreasing the specific growth rate to below that for the low-solids medium. The decreased growth rate in the higher acid concentration treatment is likely the result of thermal decomposition of the glucose.

The surface tensions of the effluent-based control media were initially in the range $60-65 \mathrm{mN} / \mathrm{m}$. The surface tensions of the low-solids and acid hydrolyzed effluent media were in the range $50-55 \mathrm{mN} / \mathrm{m}$. The biotic purified starch control medium began with a surface tension of $72 \mathrm{mN} / \mathrm{m}$ and the culture grown in it reached $31 \mathrm{mN} / \mathrm{m}$ in $24 \mathrm{~h}$, but did not change much thereafter. The surface tension in the abiotic low-solids culture remained essentially constant, with a small drop after $24 \mathrm{~h}$ to about $55 \mathrm{mN} / \mathrm{m}$. In the biotic low solids control, the surface tension increased slightly from 60 to 65 $\mathrm{mN} / \mathrm{m}$. The low solids and filtered low solids cultures again behaved identically, reaching $29 \mathrm{mN} / \mathrm{m}$ in $24 \mathrm{~h}$ and $25-27$ $\mathrm{mN} / \mathrm{m}$ after $72 \mathrm{~h}$ of culture. The behavior of the acidpretreated media was slightly different than that of the low solids culture, slowly increasing from the initial surface tension of 55 to $62 \mathrm{mN} / \mathrm{m}$, and then decreasing to $29 \mathrm{mN} / \mathrm{m}$ at $48 \mathrm{~h}$; no change in surface tension was seen after $48 \mathrm{~h}$ of culture.

Given the above findings, we concluded that autoclaving of the process effluent before use as a substrate for surfactant production was absolutely required if surfactant production is desired. If removal of particulates is necessary, this step would be better placed after surfactant production. Dilute acid hydrolysis of the diluted low-solids effluent with $1.0 \mathrm{wt} \%$ acid or higher, has a detrimental effect on growth, rate of production and total amount of surfactant produced. Pretreatment with $0.5 \mathrm{wt} \%$ acid modestly increased surfactin yield over untreated low-solids effluent. All media performed poorly on a yield-per-carbon consumed basis when compared with the optimized control culture. While it is likely that medium additions or complete sterilization of the effluent could make up this yield loss, it is unclear whether the economics of the process through the final separation step would favor feedstock additions or complete sterilization. Further studies that include separation of the surfactin will be necessary to answer this question.

\section{Continuous Surfactin Production from Agricultural Process Effluents}

In this section the initial research to combine the production of surfactin from potato process effluents with direct foam fractionation techniques is reported. Production yields of surfactin from glucose and other monosaccharides have been reported in amounts ranging from 0.1 to $0.7 \mathrm{~g} / \mathrm{L} .{ }^{5,18}$ The use of an airlift reactor to combine the production of surfactin from potato process effluents with direct foam fractionation techniques was suggested from data obtained from three potato starch runs conducted using a New Brunswick BioFlo 3000 fermentor. Each run had a working volume of $2.5 \mathrm{~L}$ and was agitated with two Rushton impellers. The first run was conducted at $2.5 \mathrm{~L} / \mathrm{min}$ of air and $200 \mathrm{rpm}$, the second run at 1 $\mathrm{L} / \mathrm{min}$ of air and $100 \mathrm{rpm}$, and the third at $0.5 \mathrm{~L} / \mathrm{min}$ of air and $100 \mathrm{rpm}$. For all three runs, the starch was utilized within $48 \mathrm{~h}$, and the foam/surfactin produced overflowed the effluent air filter. The surface tension of the liquid in the reactor decreased with increasing airflow rate, suggesting that the air was stripping the surfactin.

Combining direct production with foam fractionation has the potential to result in biologically produced surfactants with the appropriate cost profile for applications in high-volume, low-price markets such as enhanced oil recovery.

A set of experiments was performed to evaluate the effect of airflow rate on stripping of the surfactin into the foam. Three liters of culture broth (potato starch in shake flasks for $48 \mathrm{~h}$ ) containing cells and surfactin were placed in the airlift reactor. The flow of air was set at either 1.5 or $3.0 \mathrm{~L} / \mathrm{min}$. Samples of foam were collected approximately every $20 \mathrm{~min}$ over a period of $160 \mathrm{~min}$. For the $1.5 \mathrm{~L} / \mathrm{min}$ runs, the surface tension of the liquid averaged $25.5 \mathrm{mN} / \mathrm{m}$. The surfactant concentration in the foam increased to 3.5 from $1.8 \mathrm{~g} / \mathrm{L}$ in the liquid in the first $20 \mathrm{~min}$, and averaged $3.74 \mathrm{~g} / \mathrm{L}$ in the foam over the remaining $160 \mathrm{~min}$. For the $3.0 \mathrm{~L} / \mathrm{min}$ runs, the surface tension of the liquid averaged $26.5 \mathrm{mN} / \mathrm{m}$. Surfactant concentration peaked at $2.8 \mathrm{~g} / \mathrm{L}$ in the foam from $1.8 \mathrm{~g} / \mathrm{L}$ in the broth over the first $20 \mathrm{~min}$, then declined steadily to 2.3 $\mathrm{g} / \mathrm{L}$ over the remaining $160 \mathrm{~min}$. In total, $241 \mathrm{~g}$ of foam was collected at $1.5 \mathrm{~L} / \mathrm{min}$ and $1011 \mathrm{~g}$ was collected at $3.0 \mathrm{~L} / \mathrm{min}$ by $120 \mathrm{~min}$. As expected, there was higher liquid entrainment in the foam at the higher airflow rate, hence the lower concentration of surfactin. This experiment confirmed that surfactin could be stripped and concentrated into the foam. An airflow rate of $1.5 \mathrm{~L} / \mathrm{min}$ was chosen for future work.

Batch experiments utilizing purified potato starch medium were subsequently performed to test the airlift reactor. Both medium and foam were sampled over time and analyzed for carbohydrates, $\mathrm{pH}$, cell numbers, and surface tension. As the starch was utilized, the $\mathrm{pH}$ dropped and the cell numbers increased. Appreciable foam production from the top of the column did not occur until the DO approached $0 \%$. The surface tension of the foam was about $25 \mathrm{mN} / \mathrm{m}$, indicating that good stripping of the surfactin into the foam occurred.

Batch experiments utilizing potato process effluents were similar to those using purified potato starch medium. It was observed that glucose was utilized first, followed by starch. The $\mathrm{pH}$ dropped, and the cell numbers appeared to increase and then declined as the glucose and soluble starch were utilized. Foam production usually started when the DO approached $50 \%$, but foam did not overflow the headspace until the DO approached $0 \%(6 \mathrm{~h})$. As expected, there was good stripping of the surfactin from the liquid to the foam. The surface tension of the liquid was about $70 \mathrm{mN} / \mathrm{m}$, whereas the surface tension of the foam was about $30 \mathrm{mN} / \mathrm{m}$. The experiment was stopped at $35 \mathrm{~h}$ because the liquid level was approaching the bottoms of the probes.

Continuous experiments utilizing purified starch media were performed to find the highest possible dilution rate for 
operation of the reactor. The reactor was operated in batch mode for the first $25 \mathrm{~h}$ to allow cell growth and initial surfactin production. At $25 \mathrm{~h}$, media flow was started at 4.5 $\mathrm{mL} / \mathrm{min}$. Cell production increased, starch utilization occurred, DO decreased to $0 \%, \mathrm{pH}$ decreased, and surfactin production continued. Shortly after continuous operation was begun, a contaminant (believed to be carried over from the previously performed batch mode experiment with potato process effluent) was noted. Efforts to place the reactor in conditions where $B$. subtilis could out-compete the contaminant were unsuccessful as were efforts to wash out the contaminant during operations. The run was stopped, and the reactor was cleaned with hot sterile water and soaked overnight in $30 \mu \mathrm{g} / \mathrm{mL}$ tetracycline. On restart, the reactor was operated in batch mode until the DO approached $0 \%$ and foaming was robust, a time frame of about $124 \mathrm{hrs}$. After continuous operation was started, $5 \mathrm{~N} \mathrm{KOH}$ was added to control the $\mathrm{pH}$ at 7.5. After $19 \mathrm{~h}$ of continuous operation, about half of the cells appeared by direct microscopic observation not to be the inoculated $B$. subtilis. Foam production stopped sometime between 19 and $32 \mathrm{~h}$, and by 48 $\mathrm{h}$ the contaminant had again taken over the culture. It was noted that while the surfactin was present in the reactor, $B$. subtilis competed favorably. However, when surfactin was stripped from the reactor, $B$. subtilis was outcompeted by an unknown organism.

Continuous experiments using potato process effluents were performed to determine the ability of $B$. subtilis to outcompete indigenous bacteria in the potato process effluent. As observed previously, B. subtilis was outcompeted. Additionally, the surfactant produced was of very low quality with surface tensions of about $50-60 \mathrm{mN} / \mathrm{m}$. When potato process effluent was used, a certain amount of foam was produced by the proteins in the effluent. These nonsurfactin proteins in the potato process effluent added to the quantity of foam and also increased the amount of liquid carryover in the foam, thus diluting the surfactin concentration and resulting in the higher surface tension measurements.

Despite changing several operational parameters, $B$. subtilis could not outcompete the indigenous bacteria during continuous operation. This was in contrast to our experience with shake-flask experimentation. During shake flask experimentation, there was minimal foam formation and surfactin accumulated in the liquid, potentially assisting $B$. subtilis in maintaining an advantage over the indigenous bacteria. ${ }^{2,3}$ When the batch cultures were performed in the airlift reactor, the surfactin was stripped into the foam. However, there was better transfer of $\mathrm{O}_{2}$ into the liquid phase, allowing $B$. subtilis to grow and consume resources faster than the indigenous bacteria, which are fermentative, and which grow from slowly germinating $(8-12 \mathrm{~h})$ spores that survive autoclaving. ${ }^{2,3}$ By the time the spores germinated, the glucose and soluble starch levels in the batch airlift cultures were near zero. During continuous operation in the airlift reactor, surfactin was stripped into the foam as in the batch airlift cultures. However, now there was continuous addition of new substrate and additional indigenous bacteria into the reactor, in which the DO was near zero and the B. subtilis had moved into late $\log$ phase/early stationary phase growth rates. These conditions favored the indigenous potato process effluent bacteria, and B. subtilis could no longer compete.

\section{Summary}

Production of Surfactin from Starch Substrates. Surfactin, a lipopeptide biosurfactant, produced by Bacillus subtilis is known to reduce the surface tension of water from 72 to 27 $\mathrm{mN} / \mathrm{m}$. Potato substrates were evaluated as a carbon source for surfactant production by B. subtilis ATCC 21332. An established potato medium, simulated liquid and solid potato waste media, and a commercially prepared potato starch in a mineral salts medium were evaluated in shake flask experiments to verify growth, surface tension reduction, and carbohydrate reduction capabilities. Total carbohydrate assays and glucose monitoring indicated that $B$. subtilis was able to degrade potato substrates to produce surfactant. Surface tensions dropped from $71.3 \pm 0.1$ to $28.3 \pm 0.3 \mathrm{mN} / \mathrm{m}$ (simulated solid potato medium) and to $27.5 \pm 0.3 \mathrm{mN} / \mathrm{m}$ mineral salts medium). A CMC of $0.10 \mathrm{~g} / 1$ was obtained from a methylene chloride extract of the simulated solid potato medium.

Production of Surfactin from Agricultural Process Effluents. High-solids and low-solids potato process effluents were tested as substrates for surfactin production. Tests used 1/10-diluted effluents, unamended or amended with trace minerals or corn steep liquor. Heat pretreatment was necessary for surfactin production from effluents due to indigenous bacteria, spores from which remained after autoclaving. Surfactin production from low-solids surpassed high-solids in all cases. Surfactin yields from low-solids effluent were $66 \%$ lower than from a pure culture in an optimized potato starch medium. Low-solids effluent could potentially be used without sterilization for surfactin production for low-value applications such as environmental remediation or oil recovery.

The Effect of Pretreatment of Agricultural Process Effluents on Surfactin Production. Pretreatments of lowsolids potato process effluent were tested for potential to increase surfactin yield. Pretreatments included heat, removal of starch particulates, and acid hydrolysis. Elimination of contaminating vegetative cells was necessary for surfactin production. After autoclaving, $0.40 \mathrm{~g} / \mathrm{L}$ of surfactin was produced from the effluent in $72 \mathrm{~h}$, versus $0.24 \mathrm{~g} / \mathrm{L}$ in the purified potato starch control. However, surfactin yields per carbon consumed were $76 \%$ lower from process effluent. Removal of starch particulates had little effect on the culture. Acid hydrolysis decreased growth and surfactant production, except $0.5 \mathrm{wt} \%$ acid, which increased the yield by $25 \%$ over untreated effluent 
Continuous Surfactin Production from Agricultural Process Effluents. An airlift reactor can be used to combine the production and recovery of surfactin from purified starch medium with direct fractionation techniques in good yield. When producing surfactin from potato process effluent in the airlift reactor, which contains recalcitrant indigenous bacteria and significant amounts of protein, both production and recovery are hampered. It is likely that removal of the foam, which contains the surfactin, may allow the indigenous bacteria to outcompete the inoculated B. subtilis.

Currently, we are studying ways to rectify these issues including using (1) a larger inoculum of $B$. subtilis grown on potato starch, (2) $\mathrm{pH}$ control, (3) pressurized reactor operations, and (4) the growth and recovery of surfactin in a semibatch reactor system (swing columns). Additionally, we are evaluating the effluent population dynamics with respect to reactor operations.

\section{Acknowledgment}

This work was supported by the US Department of Energy, Assistant Secretary for Fossil Energy, Office of Fossil Energy, under contract nos. DE-AC07-94ID13223 and DE-AC0799ID13727. The authors thank Jerry Casteel, Rhonda Lindsey, Purna Halder and Daniel Gurney of the US DOE National Petroleum Technology office and Patricia St. Clair of the US DOE Idaho Field Office for their support. The authors also express their gratitude for the generous help and support of Arthur Kull, Thomas Owings and Henry Camin of Basic American Foods, Blackfoot, ID. The technical assistance of Rick Scott and Robert V. Fox for surface tension measurements and FTIR was also greatly appreciated.

\section{References}

1. Fox, S.L. and Bala, G.A. "Production of surfactant from Bacillus subtilis ATCC 21332 using potato substrates." (2000). Bioresource Technology, 75 pp. $235-240$.

2. Thompson, D.N., Fox, S.L., and Bala, G.A. "Biosurfactants from Potato Process Effluents." (2000). Applied Biochemistry and Biotechnology, Vol. 84-86. pp. 917-930.

3. Thompson, D.N., Fox, S.L., and Bala, G.A. "The Effect of Pretreatment on Surfactin Production from Potato Process Effluent by Bacillus subtilis." (2001). Applied Biochemistry and Biotechnology. Vol. 91-93. pp. 487-501.

4. Noah, K.S, Fox, S.L., Bruhn, D.F., Thompson, D.N., and Bala, G.A. "Development of Continuous Surfactin Production from Potato Process Effluent by Bacillus subtilis in an Airlift Reactor." (2002). Applied Biochemistry and Biotechnology. In Press.

5. Georgiou, G., Lin, S.C., and Sharma, M.M. "Surface Active Compounds from Microorganisms." (1992). Bio/Technology 10 60-65.

6. Rosenberg, E. "Microbial Surfactants." CRC Critical Reviews in Biotechnology. (1986) 3(3) 109-132.

7. Peypoux, F., Bonmatin, J.M., and Wallach, J. "Recent Trends in the Biochemistry of Surfactin." (1999). Appl. Microbiol. Biotechnol. 51, 553-563.

8. Vater, J. "Lipopeptides, an Attractive Class of Microbial Surfactants.” (1986). Prog. Colloi. Polym. Sci. 72, 12-18
9. Lin, S.C. "Biosurfactants, Recent Advances." J. Chem. Tech. Biotechnol. (1996). 66, 109-120.

10. Fox, S.L., Brehm, M.A., Robertson, E.P., Jackson, J.D., Thomas, C.P., and Bala, G.A. "Comparative Analysis of Microbially Mediated Oil Recovery by Surfactants Produced by Bacillus licheniformis and Bacillus subtilis." (1993). In Developments in Petroleum Science, Premuzic, E.T., Woodhead, A. (Eds). Elsevier, Now York, pp. 143-150.

11. Bala, G.A., Duvall, M.L, Barrett, K.B., Robertson, E.P., Pfister, R.M., and Thomas, C.P. "Surfactant Based Microbial Enhanced Oil Recovery (MEOR)." (1991). In Mineral Bioprocessing, Smith, R.W., and Manoranjan, M. (Eds). The Minerals, Metals, \& Materials Society. pp. 121-132.

12. Bala, G.A., Herd, M.D., Robertson, E.P., Duvall, M.L., and Thomas, C.P. "Surfactant Mediated Microbial EOR of Medium to Heavy Crude Oils. (1991) Proceedings of the 1991 Eastern Oil Shale Symposium, Institute for Mining and Minerals Research, University of Kentucky. pp. 158-166.

13. Thomas, C.P., Duvall, M.L., Robertson, E.P., Barrett, K.B., and Bala, G.A.. "Surfactant-Based EOR Mediated by Naturally Occurring Microorganisms." SPERE (November 1993) pp. 285291.

14. Gherna, P., Pienta, P. (eds.) "How to store bacterial strains." In American Type Culture Collection Catalog of Bacteria and Phages. $17^{\text {th }}$ Ed. ATCC, Maryland, p. 403.

15. Daniels, L., Hansen, R.S., and Phillips, J.A. "Chemical Analysis," in Methods for General and Molecular Bacteriology. Gerhardt, P., Murray, G.G.E., Wood, W.A., and Krieg, N.R. (eds). American Society for Microbiology, Chapter 22. pp. 518-519.

16. Bailey, J.E., and Ollis, D.F. Biochemical Engineering Fundamentals, $2^{\text {nd }}$ Edition. (1986). McGraw Hill, New York, New York

17. Herd, M.D., Lassahn, G.D., Thomas, C.P., Bala, G.A., and Eastman, S.L., "Interfacial Tensions of Microbial Surfactants Determined by Real-Time Video Imaging of Pendant Drops," (1992). Proceedings of the DOE Eighth Symposium on Enhanced Oil Recovery SPE/DOE 24206.

18. Cooper, D.G., MacDonald, C.R., Duff, S.J.B., Kosaric, N., "Enhanced Production of Surfactin from Bacillus subtilis by Continuous Product Removal and Metal Cation Additions." (1981). Appl. Environ. Microbiol. 42, 408-412.

19. Sheppard, J.D., Mulligan, C.N. "The Production of Surfactin by Bacillus subtilis grown on Peat Hydrolysate," Appl. Microbiol. Biotechnol. (1987). 27, 110-116.

20. Lin, S.C. and Jiang, H.J. "Recovery and purification of the lipopeptide biosurfactant of Bacillus subtilis by ultrafiltration, " Biotechnol. Techniques (1997). 11(6), 413-416.

21. Moo-Young, M. Blanch, H.W. Drew, S. and Wang, D.I.C. Comprehensive Biotechnology: The Principals, Applications, and Regulations of Biotechnology in Industry, Agriculture, and Medicine. (1985). Vol. 3, Pergamon Press, New York. pp. 1948.

22. Bozell, J.J. and Landucci, R. Alternative Feedstocks Program Technical and Economic Assessment: Thermal/Chemical and Bioprocessing Components. U.S. Department of Energy Office of Industrial Technologies, Washington, DC. pp. 11-226.

23. Polman, K. Bala, G.A., and St. Clair, P. "Models for the Biological Production of Glycerol and Biosurfactants from Potato-Processing Industry Residuals." (1995). Scientific Note in Applied Biochemistry and Biotechnology. Vol 51-52. pp. 511518. 
24. Sheppard, J.D., Cooper, D.G. "The Response of Bacillus subtilis ATCC 21332 to Manganese during Continuous-Phased Growth." (1991). Appl. Microbiol. Biotechnol. 35, 72-76.

25. Koch, A.L. "Growth Measurement" (1994). In Methods for General and Molecular Bacteriology, Gephardt, P. (Ed.) ASM, Washington, DC, pp. 251-252.

\begin{tabular}{lccc}
\hline & \multicolumn{3}{c}{ Starch Source } \\
\cline { 2 - 4 } Carbon Source (g/L) & Purified Potato & $1: 10 \mathrm{HS}$ & $1: 10 \mathrm{LS}$ \\
& Starch Medium & Effluent & Effluent \\
\hline Glucose & 0.009 & 0.016 & 0.44 \\
Soluble Starch & 4.88 & 4.69 & 14.6 \\
Insolubles* & 0.001 & 16.2 & 6.57 \\
\hline & & & \\
*Starch + other & & \\
\hline
\end{tabular}

Table 1: Characterization of substrates for purified potato starch control and for potato process effluents as used for experimentation. Concentrations are after autoclaving. High-solids (HS) and low-solids (LS) designations are based on the wt\% of insolubles present.

\begin{tabular}{lc}
\hline Effluent Component & $\begin{array}{c}\text { Concentration } \\
(\mathrm{g} / \mathrm{L})\end{array}$ \\
\hline Soluble Starch & 128. \\
Insoluble Starch / Fiber & 14. \\
Glucose & 5.2 \\
Fructose & 3.0 \\
Galactose & $<0.30$ \\
Sucrose & 9.7 \\
Maltose & 9.1 \\
Lactose & 0.30 \\
Protein & 72. \\
Ca & 0.98 \\
Cu & 0.0021 \\
Fe & 0.012 \\
$\mathrm{Mg}$ & 1.1 \\
$\mathrm{Mn}$ & 0.0044 \\
$\mathrm{P}$ & 2.0 \\
$\mathrm{~K}$ & 23. \\
$\mathrm{Na}$ & 1.3 \\
$\mathrm{Zn}$ & 0.011 \\
\hline & \\
Total NH & Nitrogen \\
Total Ash & 12. \\
\hline
\end{tabular}

Table 2: Average composition of low-solids potato process effluent as received from the processor. Effluent media were prepared using 1:10 $(\mathrm{v} / \mathrm{v})$ dilutions of this effluent.

\begin{tabular}{lccc}
\hline & \multicolumn{3}{c}{$\begin{array}{c}\text { Fraction of Initial } \\
\text { (After Pretreatment) }\end{array}$} \\
\cline { 2 - 4 } Pretreatment & \multicolumn{3}{c}{ Soluble } \\
\hline None & 1.00 & 1.00 & 1.00 \\
Heat & 0.801 & 1.18 & 1.96 \\
Filtered $+\mathrm{Heat}$ & 0.816 & 1.45 & 2.04 \\
$0.5 \mathrm{wt} \% \mathrm{H}_{2} \mathrm{SO}_{4}$, Heat to $121^{\circ}$ & 1.68 & 1.02 & 1.86 \\
$1.0 \mathrm{wt} \% \mathrm{H}_{2} \mathrm{SO}_{4}$, Heat to $121^{\circ}$ & 1.79 & 0.900 & 1.86 \\
$2.0 \mathrm{wt} \% \mathrm{H}_{2} \mathrm{SO}_{4}$, Heat to $121^{\circ}$ & 3.81 & 0.807 & 1.87 \\
\hline
\end{tabular}

Table 3: Effect of pretreatments on relative substrate concentrations in pretreated diluted low-solids effluent. All pretreatments included autoclaving the substrate at $121^{\circ} \mathrm{C}$ for 20 minutes. The biotic lowsolids effluent control substrate was not autoclaved. Note that "Soluble Starch" includes all reducing sugars other than free glucose.

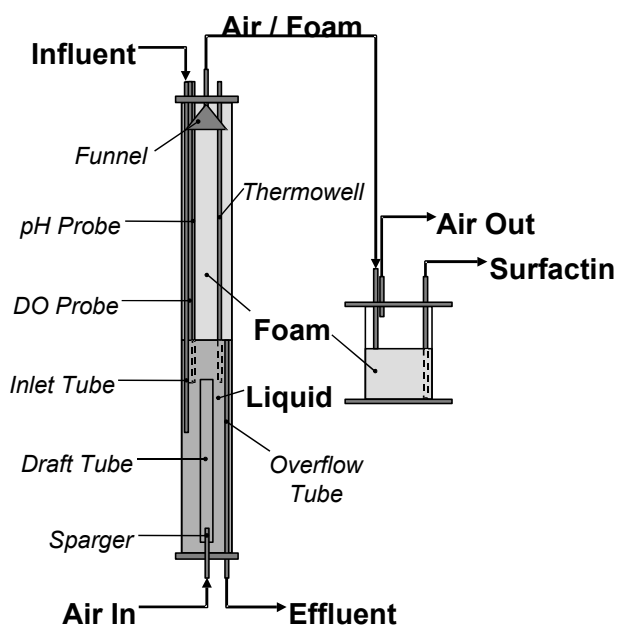

Figure 1. Schematic of airlift reactor

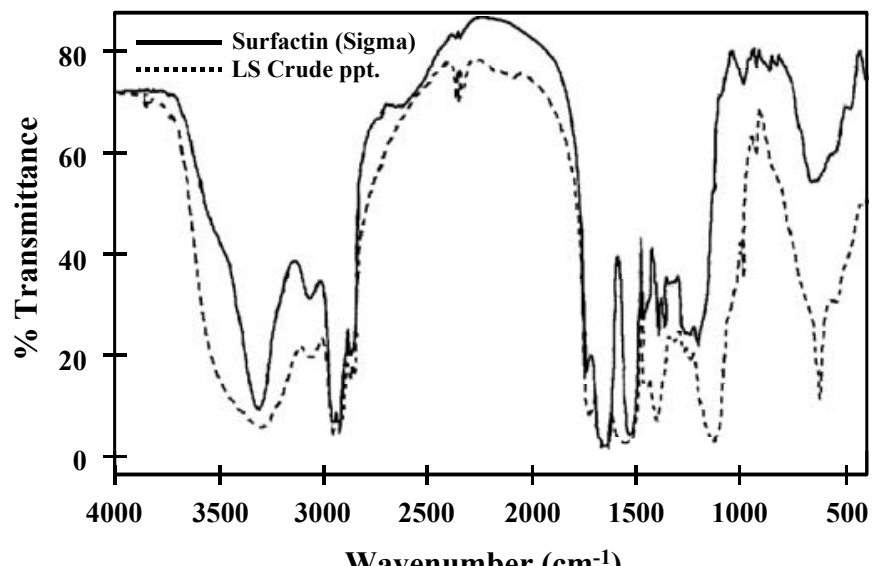

Figure 2: Transmission FTIR spectra of purified commercial surfactin (Sigma) and the crude precipitate produced by $B$. subtilis grown on low-solids potato process effluent. 


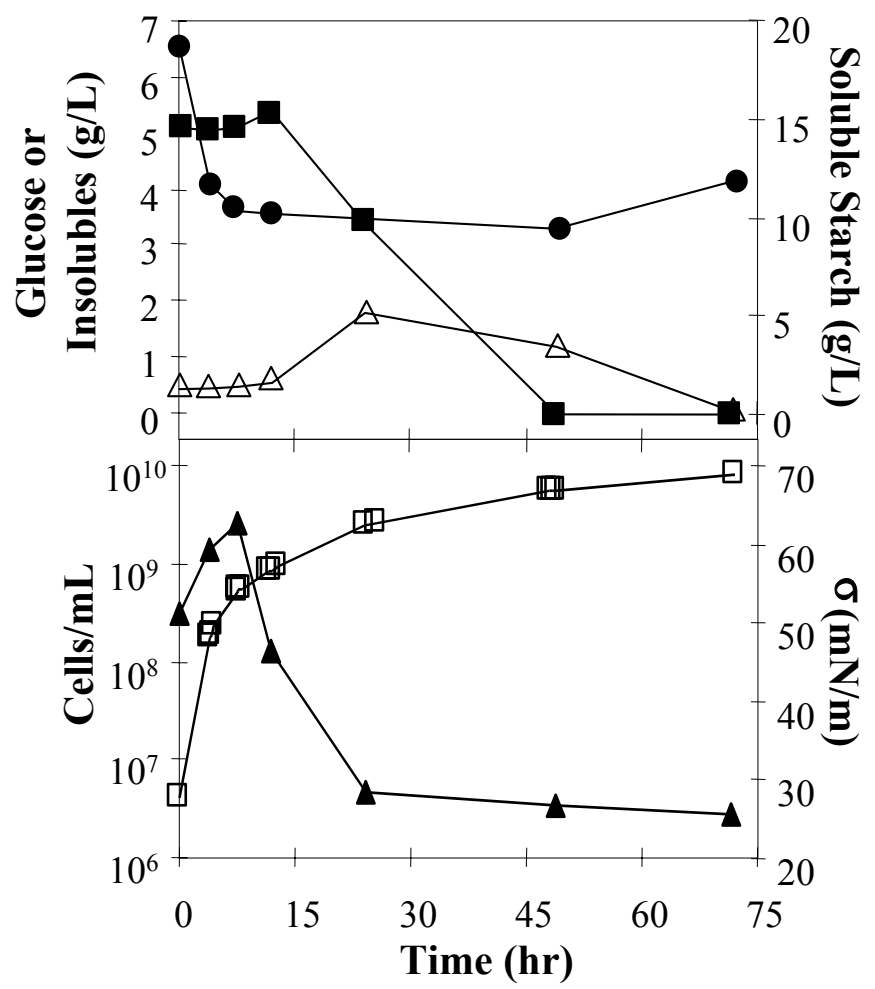

Figure 3: Time courses of all measured culture parameters for the LS culture. Symbols are: $(\boldsymbol{\bullet})$ Soluble starch; $(\bullet)$ Insoluble starch; $(\Delta)$ Glucose; (口) Cells/mL; ( $\mathbf{\Lambda})$ Surface tension. 